\title{
ALTERATIONS IN ELECTRICAL RESISTIVITY OF SANDY SOIL IN CONTROLLED EXPERIMENT BY INFILTRATION OF STILLAGE
}

\author{
ALTERAÇÕES NA RESISTIVIDADE ELÉTRICA DO SOLO ARENOSO EM EXPERIMENTO POR \\ INFILTRAÇÃO DE VINHAÇA CONTROLADO
}

\author{
Cesar Augusto MOREIRA ${ }^{\mathbf{1}}$, José Ricardo Melges BORTOLIN², Walter MALAGUTTI \\ FILHO $^{1}$, João Carlos DOURADO ${ }^{1}$ \\ ${ }^{1}$ Departamento de Geologia Aplicada (DGA), Instituto de Geociência e Ciências Exatas, Universidade Estadual Paulista. \\ Av. 24-A, 1515 - Bela Vista - Rio Claro - SP - CEP. 13506-900, CP-178 \\ Emails: moreirac@rc.unesp.br; malaguti@rc.unesp.br; jdourado@rc.unesp.br \\ ${ }^{2}$ Fundação Hermínio Ometto - Uniararas. Email: jrmb@bol.com.br
}

\author{
Introduction \\ Study Area \\ Results \\ Conclusions \\ Acknowledgements \\ References
}

\begin{abstract}
The sugar and alcohol sector represents one of the most profitable economic activities in Brazil, being ethanol one of the main products. Among the residues related to the production of ethanol, it is highlighted the stillage, a liquid substance generated in the approximate proportion of 13 liters for each liter of ethanol produced. This paper presents the results of a stillage infiltration experiment, in various proportions, through trenches in sandy soil, with the aim to evaluate possible alterations in electrical properties in the geological materials, in individual experiments, with $60 \mathrm{~L}, 300 \mathrm{~L}$ and $900 \mathrm{~L}$ of effluent. The initial proportion was defined based on a standard stipulated by the Environmental Agency of the State of São Paulo, which considers the cation exchange capacity of the soil, while the other quantities were defined from ratios of 4 and 15 times higher than those defined by legislation. The experiment was monitored by means of electrical resistivity measurements by indirect means through the geophysical method of Electroresistivity. The data indicate the absence of alterations in electrical properties in the soil below the point of infiltration in the experiment for $60 \mathrm{~L}$ of stillage. The data for infiltrations with $300 \mathrm{~L}$ and $900 \mathrm{~L}$ revealed a zone of low resistivity below the infiltration point, basically limited to the $1 \mathrm{~m}$ layer of sandy soil and with tendency for lateral flow supported by the soil/rock interface. The results demonstrate that the infiltration of inorganic solutions, in a proportion inferior to the cation exchange capacity of the soil, does not perceptibly alter its electrical properties in studies using the geophysical method of Electro resistivity, whereas proportions that exceed natural absorption capacity are characterized by the geoelectric signature of low resistivity.
\end{abstract}

Keywords: stillage, permeability, electrical resistivity, cation exchange capacity.

RESUMO - O setor sucroalcooleiro representa uma das mais rentáveis atividades econômicas do Brasil, sendo o etanol um dos principais produtos. Dentre os resíduos relacionados à produção de etanol, destaca-se a vinhaça, substância líquida gerada na proporção aproximada de 13 litros para cada litro de etanol produzido. Este artigo apresenta os resultados de um experimento de infiltração de vinhaça, em várias proporções, por meio de valas em solo arenoso, com o objetivo de avaliar eventuais alterações em propriedades elétricas nos materiais geológicos, em experimentos individuais, com $60 \mathrm{~L}, 300 \mathrm{~L}$ e $900 \mathrm{~L}$ de efluente. A proporção inicial foi definida a partir de norma estipulada pela Agência Ambiental do Estado de São Paulo que considera a capacidade de troca catiônica do solo, ao passo que as demais quantidades foram definidas a partir de proporções de 4 e 15 vezes superiores ao definido por legislação. $\mathrm{O}$ experimento foi monitorado por meio de medidas de resistividade elétrica de forma indireta através do método geofísico da Eletrorresistividade. Os dados indicam a inexistência de alterações em propriedades elétrica no solo abaixo do ponto de infiltração no experimento para 60L de vinhaça. Os dados para infiltrações com 300L e 900L revelaram uma zona de baixa resistividade abaixo do ponto de infiltração, basicamente limitada à camada de $1 \mathrm{~m}$ de solo arenoso e com tendência de fluxo lateral suportada pela interface solo/rocha. Os resultados demonstram que a infiltração de soluções inorgânicos, em proporção inferior à capacidade de troca catiônico do solo, não altera suas propriedades elétricas de forma perceptível em estudos por meio do método geofísico da eletrorresistividade, ao passo que proporções que excedam capacidade de absorção natural são caracterizadas pela assinatura geoelétrica de baixa resistividade.

Palavras-chave: vinhaça, permeabilidade, resistividade elétrica, capacidade de troca catiônica.

\section{INTRODUCTION}

The effects of the 1973 oil crisis were felt in all oil and oil-derivate importing countries, which consisted essentially of a drastic price increase over a few weeks by the main oil producers, gathered in a cartel named OPEC (Organization of Petroleum Exporters
Countries). At the time, Brazil depended mainly on imports of hydrocarbons to maintain the fleet of cars and, mainly, trucks responsible for the logistics of transporting machinery, equipment and food throughout the country.

One of the government policies to reduce 
dependence on hydrocarbons imports was the investment in research and development of alternative fuel sources through action on two action fronts.

Brazil was one of the world's leading sugar producers, obtained from the processing of sugarcane, cultivated on hundreds of hectares of planted area. In this sense, the first line of action was the liberation of credit lines for the conversion of sugar production plants into alcohol producers, in a period when there was an excess supply of product on the world market and consequent fall in prices. The second front of action was the financing of studies and projects for the development of alcohol engines in national research institutes, from partnerships with vehicle assemblers installed in the country. This set of actions was implemented since 1980 in Brazil under the name of Proálcool (National Alcohol Program), started in the country in 1975 (BRAZIL, 1975).

Proálcool was the first large-scale global initiative to replace fossil fuels by renewable fuels, which has resulted in the progressive conversion of the fleet of light vehicles manufactured in the country by engines powered by fuel alcohol. Currently, the Brazilian national fleet consists of approximately 90 million vehicles, of which approximately $38 \%$ use hybrid engines powered by both gasoline and ethanol (DENATRAN, 2015).

Alcohol, ethanol or ethyl alcohol is an organic substance $\left(\mathrm{CH}_{3} \mathrm{CH}_{2} \mathrm{OH}\right)$ originated from the fermentation of sugars, which in Brazil is obtained from sugarcane in 384 processing units spread throughout the national territory (CONAB, 2013).

This process consists of the grinding of the organic matter and the production of broth or must, later filtered and fermented and distilled, which results primarily in the production of hydrous ethanol with $96^{\circ} \mathrm{GL}$ content and supplied directly as fuel ethanol, as well as a second product submitted to distillation process that results in anhydrous ethanol with $99^{\circ} \mathrm{GL}$, which is used as an additive in proportions ranging from $23 \%$ to $27 \%$ in common gasoline (Santos, 2013).

For each 1000 tons of processed sugar cane, $96 \mathrm{~L}$ of sugar and $36000 \mathrm{~L}$ of alcohol are obtained, in addition to almost 70 other secondary products and 4 different types of residues, of which stillage is one of the most relevant due to the large quantity produced (ICIDCA, 1999; CETESB, 2002). Stillage is a liquid residue obtained in the fractional distillation operation of the fermented cane broth, generated in the proportion of $13 \mathrm{~L}$ for each liter of ethanol produced, that is, about $468000 \mathrm{~L}$ of stillage are generated for every 1000 tons of sugar cane or 36000L of ethanol (González \& Garlobo, 1999).

The stillage is chemically characterized by high corrosion power, acidity, high electrical conductivity and high levels of Biochemical Oxygen Demand (BOD) and Chemical Oxygen Demand (COD), basically composed of $93 \%$ water and $7 \%$ solids as soluble organic matter and mineral salts (Ludovice, 1997). The discharge of this process residue into rivers was frequent until 1980 when it was banned, and often resulted in intense fish mortality due to the eutrophication of the water caused by the sequestration of oxygen for the consumption of soluble organic matter (CETESB, 2006).

Currently the stillage is used as fertilizer in sugarcane crops by means of the fertirrigation technique, to take advantage of the organic and mineral fraction (mainly $\mathrm{K}^{+}, \mathrm{Na}^{+}, \mathrm{Mg}^{2+}$ and $\mathrm{Ca}^{2+}$ ). The volume of stillage to be applied per unit of area is based on the effective absorption of the macronutrients by the crop and by the degradation and incorporation of the organic matter present in the stillage by the soil biota. This calculation is based on the element of higher content - in this case, potassium - for the macronutrients and/or the amount of organic matter that the soil supports to receive. Failure to observe this and other technical precautions may result in severe impacts on soil and groundwater such as: saturation, by nutrients, and soil pollution; degradation of planting areas; percolation of chemical elements and contamination of groundwater, mainly by the transfer of significant concentrations of ammonia, magnesium, aluminum, iron, manganese, chlorides and organic matter (Hassuda et al., 1990).

Traditionally, investigations of the influence of stillage in soils and groundwater are carried out through physical-chemical analyzes, in soil and water samples collected in areas of sugarcane cultivation (Hassuda, 1989; Gloeden et al., 1991; 
Ludovice, 1997; Lyra et al., 2003; Silva et al., 2006; Brito et al., 2007; Cruz, 2008; Oliva \& Chang, 2011; Silva et al. 2014). The quantification of contents is the main advantage of this investigation procedure, to the detriment of the low sampling representativity due to the punctual and localized character of the samples, which may compromise or hinder studies in large areas, due to the high cost with collection and analysis of an adequate and representative set of data.

The use of geophysical methods in the study of the consequences of stillage infiltration and flow in soil is a feasible alternative in physical impact studies, with high density and representativeness sampling, based on the contrast of physical properties intrinsic to the geological materials. In this sense, the present work presents and discusses the results of geophysical tests using the Electroresistivity method, with the use of the electric imaging technique, in an experiment of controlled infiltration of stillage, based on the CETESB standard, in an attempt to evaluate the geoelectric signature and its temporal variation, in sandy soil.

\section{STUDY AREA}

The study area is located in the rural area of the municipality of Corumbataí, in the central-eastern region of the State of São Paulo, in a pasturecovered site where two trenches were opened for controlled stillage infiltration (Figure 1).

Geological descriptions exposed on the access roads to the area reveal the occurrence of sandstones of the Pirambóia Formation, essentially characterized by medium and fine granulometry with plane-parallel stratification and colorings ranging from white to red (Schneider et al. 1974; Lopes et al. 2005), in addition to local occurrences of thin layers of siltstones (Figure 1A).
The intemperate action on this rock resulted in homogeneous sandy soils, weakly consolidated and light brown colored (Figure 1B) in which base occurs the free local aquifer level at depths ranging from $8 \mathrm{~m}$ to $12 \mathrm{~m}$.

Soil infiltration tests were carried out to measure hydraulic conductivity in the local soil with the aid of a Guelph-type permeameter, where values varying between $1,24 \times 10^{-3}$ to $2,94 \times 10^{-4}$ were found, compatible with sandy soils of silt matrix (Melo \& Teixeira, 1967). The area presents a gentle slope with an average of $5 \%$ in the NE heading.

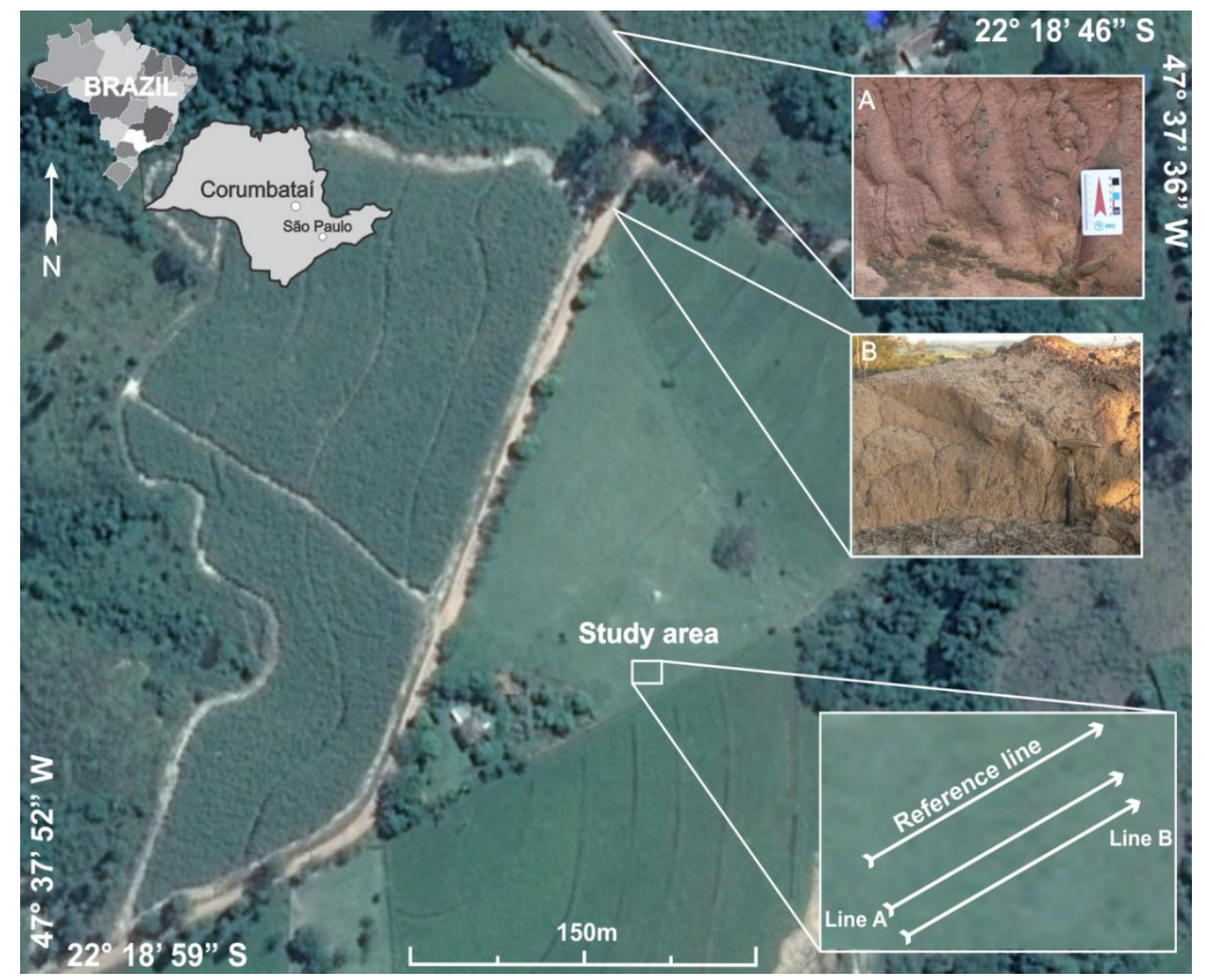

Figure 1 - Location of the study area. A) Exposure of medium red sandstone with parallel flat lamination. B) Sandy light brown soil. 


\section{MATERIALS AND METHODS}

From the geological, pedological and soil infiltration tests, two trenches with an approximate size of $0.45 \mathrm{~m} \times 0.45 \mathrm{~m} \times 2,00 \mathrm{~m}$ were opened for controlled infiltration of stillage (Figure 2).

The amount of infiltrated stillage was defined according to the standard P4.231 of CETESB (2006), which considers the Cation Exchange Capacity (CEC) of the soil and the concentrations of potassium in stillage $\left(\mathrm{k}_{\mathrm{vi}}\right)$ and soil $\left(\mathrm{k}_{\mathrm{s}}\right)$, which allowed to define the value of $60 \mathrm{~L} / \mathrm{m}^{2}$ for the study area. The stillage infiltration in the trenches was performed in two stages: in the first, 60L were

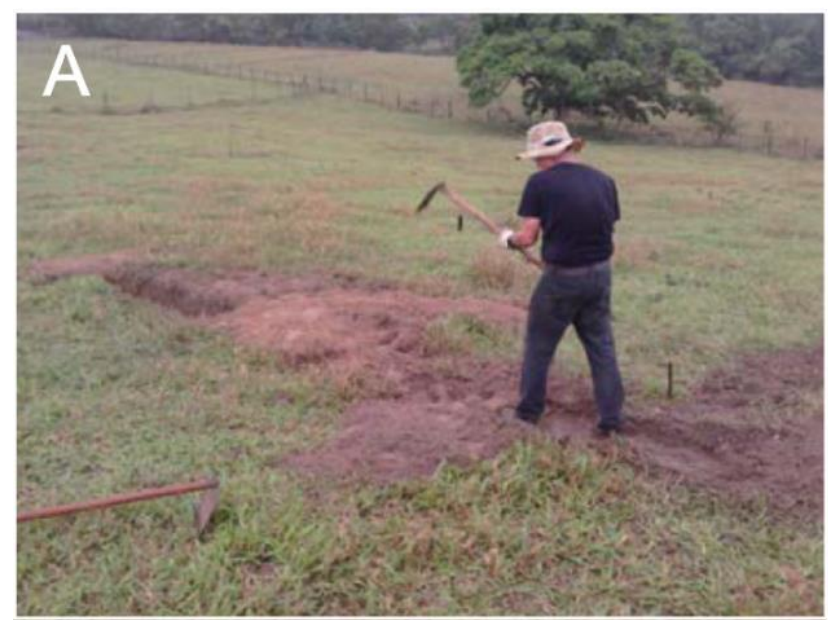

infiltrated in the trench $\mathrm{A}$ and $300 \mathrm{~L}$ in the trench B. In a second stage of infiltration other $900 \mathrm{~L}$ were dumped into trench B after 1 month of the latest infiltration. This procedure consisted of a strategy to evaluate the variations in electric properties in the soil, in proportions indicated by legislation, and in volumes 4 and 15 times greater than allowed. The development of the experiment occurred during the dry season in the region resulting, therefore, in a data set missing the influence of changes possibly related to the degree of moisture in the soil, due to rainfall occurrence.

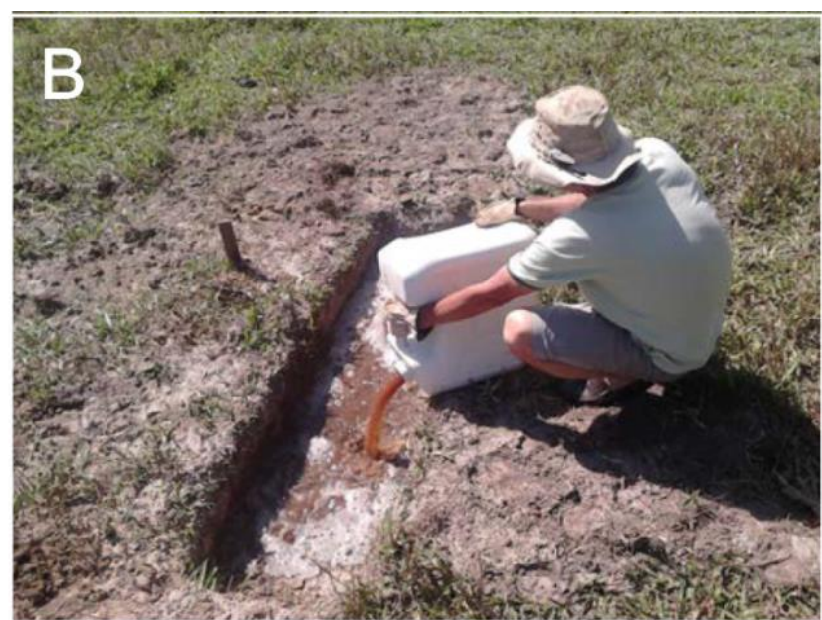

Figure 2 - Sequence of preparation of the experiment. A) Opening of the trenches. B) Controlled stillage infiltration.

The electrical imaging technique is based on the realization of apparent resistivity measurements along a profile in order to investigate variations in one or more levels in depth (Ward, 1990).

The dipole-dipole array is characterized by using equal spacing between electrodes $\mathrm{AB}$ and $\mathrm{MN}$, with a center displacement of both the dipoles along the line (Telford et al., 1990). In this study the distance between electrodes $\mathrm{AB}=$ $\mathrm{MN}=3 \mathrm{~m}$ with eight levels of investigation was used.

Resistivity ( $\rho$ ), using the dipole-dipole, is calculated by:

$$
\rho=K \frac{\Delta V}{I} \quad \text { Equation } 1
$$

where $\Delta V=$ potential difference measured between the $\mathrm{M}$ and $\mathrm{N}$ electrodes (in $\mathrm{V}$ ); $I=$ electrical current applied to the soil via the electrodes A and B (in A); $K=$ geometric coefficient dependent on the used array. For dipole-dipole $\mathrm{K}$ is given by:

$$
K=2 \pi \frac{1}{\left(\frac{1}{n}-\frac{2}{n+1}+\frac{1}{n+2}\right)} \quad \text { Equation } 2
$$

the coefficient $\mathrm{n}$ represents the investigation level and can assume only whole values, i.e., $n$ $=1,2,3$,

The dipole-dipole array was chosen because it is a symmetrical array, that provides good quality information in both horizontal and vertical directions (Kearey et al. 2002). The data acquisition was made with an ABEM Terrameter SAS 4000 resistivity meter. The geophysical tests were initiated by preliminary readings to the infiltration of stillage, for the knowledge of the natural patterns of the area, in 2 lines of essays named Lines A and B, whose measurements served as reference for the comparison with the following results. In continuation, the tests were performed in two steps as the stillage was infiltrated in larger volumes. In a first step 60L were dumped in the trench $\mathrm{A}$ and $300 \mathrm{~L}$ of stillage in the trench B and electrical imaging tests were carried out, 
with resistivity readings, in the times of $24 \mathrm{hs}$, $72 \mathrm{hs}, 192 \mathrm{hs}$ and $240 \mathrm{hs}$, after the infiltration. Subsequently, 900L of stillage were dumped in Line B trench and electrical imaging tests were performed, at the same times, after infiltration. (Figure 3). The reference section, shown in the figure, shows the results of measurements performed pre-infiltration.

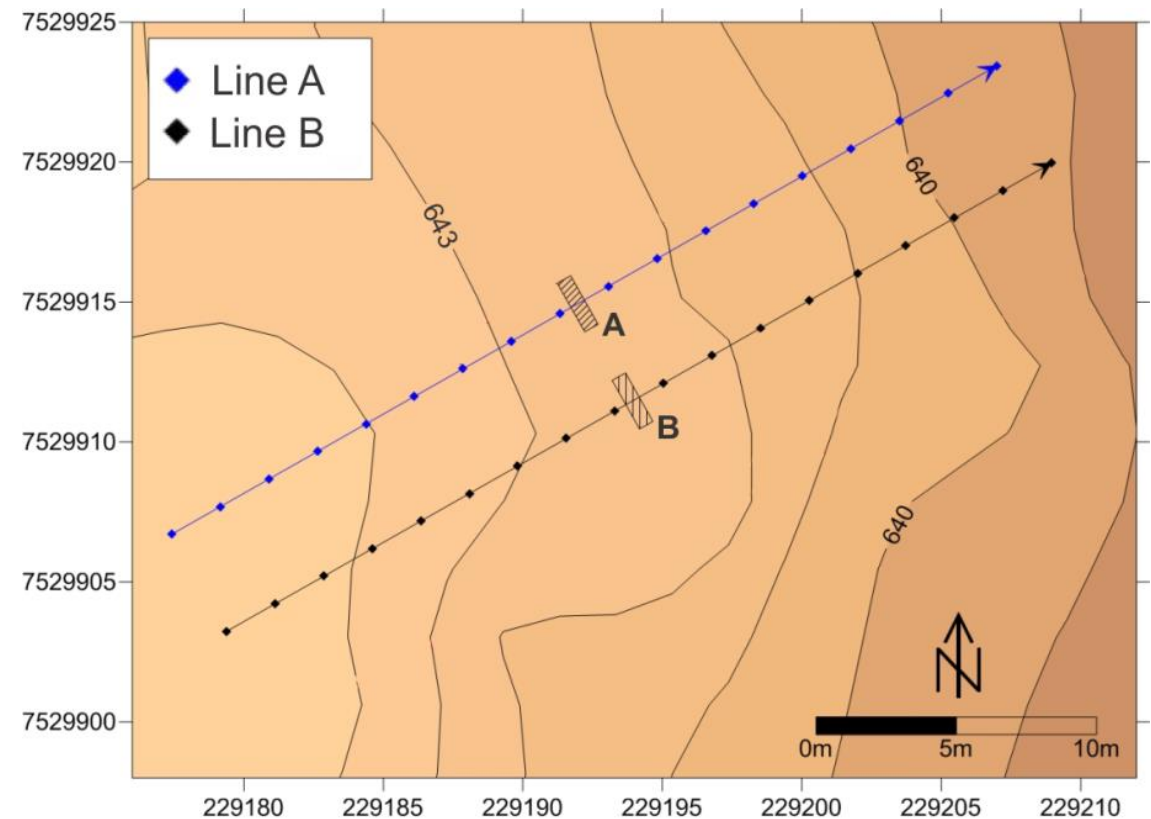

Figure 3 - Arrangement of the electric imaging lines, superimposed on the local topography and infiltration trenches.

\section{RESULTS}

Measurements acquired in field were processed in the Res2dinv program and resulted in resistivity sections in terms of distance $x$ depth, with logarithmic graph scale and color value interpolation intervals (Figures 4, 5 and $6)$. This program automatically determines a two-dimensional subsurface model, from resistivity data obtained in electrical imaging trials (Griffiths \& Barker, 1993).

The 2D model, used in the program, divides the pseudo-section into rectangular blocks, which will represent the pseudo-section by adjusting the field measurements (Edwards, 1977). This optimization aims to reduce the difference between the apparent resistivity values, calculated and measured in the field, by the adjustment of the resistivity of the blocks model, whose difference is expressed by the RMS (Root Mean Square) error (Loke \& Barker, 1996).

The initial processing of the sections enabled a previous verification and elaboration of a single scale of values, which provides a comparative analysis of the results. Results were united in three sets based on the quantity of infiltrated stillage: the first set refers to the infiltration of 60L (trench A), the second presents the results for $300 \mathrm{~L}$ (trench B) and the third was generated after the infiltration of $900 \mathrm{~L}$ (trench B). In the three sets the reference section is shown, with natural resistivity values for the area, obtained previously to the stage of stillage infiltration.

The analysis of the set of results for $60 \mathrm{~L}$ of stillage shows that basically there were no changes in the values of electrical resistivity below the stillage infiltration site (Figure 4). It is important to emphasize that this volume of stillage was calculated based on the cation exchange capacity of the soil, that is, the volume of stillage infiltrate must, in theory, be totally absorbed and retained in the soil, to later serve as fertilizer to agricultural crops as the sugarcane.

The set of results for 300L of stillage shows a zone of low resistivity very pronounced below the point of infiltration, with values of up to $100 \Omega . m$ in the center of the zone (Figure 5). This trend is evident in the section obtained after 24 hours of infiltration and maintained in the other sections, accompanied by a small increase in the area of low resistivity. This data set indicates that the area of electrical resistivity change was restricted to the vicinity of the infiltration point and up to $1 \mathrm{~m}$ deep, with no evidence of attenuation or tendency to return to the natural values.

The results for $900 \mathrm{~L}$ of stillage also show an area of low electrical resistivity exactly below 
the point of infiltration, similar to the case of infiltration of $300 \mathrm{~L}$.

However, in this case, although the resistivity values also reach $100 \Omega . \mathrm{m}$ in the central zone, the dimensions of the low resistivity area are relatively larger (Figure 6). The section related to $72 \mathrm{hs}$ presents a discontinuity in the shape of the central zone of the anomaly, contrasting with those defined in the section for $24 \mathrm{hs}$ and later in the sections of $192 \mathrm{hs}$ and $240 \mathrm{hs}$. Possible explanations for this would be a high contact resistance at some electrode in the center of the acquisition line, or a possible punctual discrepancy in some value(s) collected, for this line specifically.

Anyway, the integrated analysis of this dataset describes a typical pattern of ionic solution flow in porous soil, with gradual increase of low resistivity area with the time of effluent propagation. This increase is basically conditioned to lateral expansion and limited to $1 \mathrm{~m}$ depth.
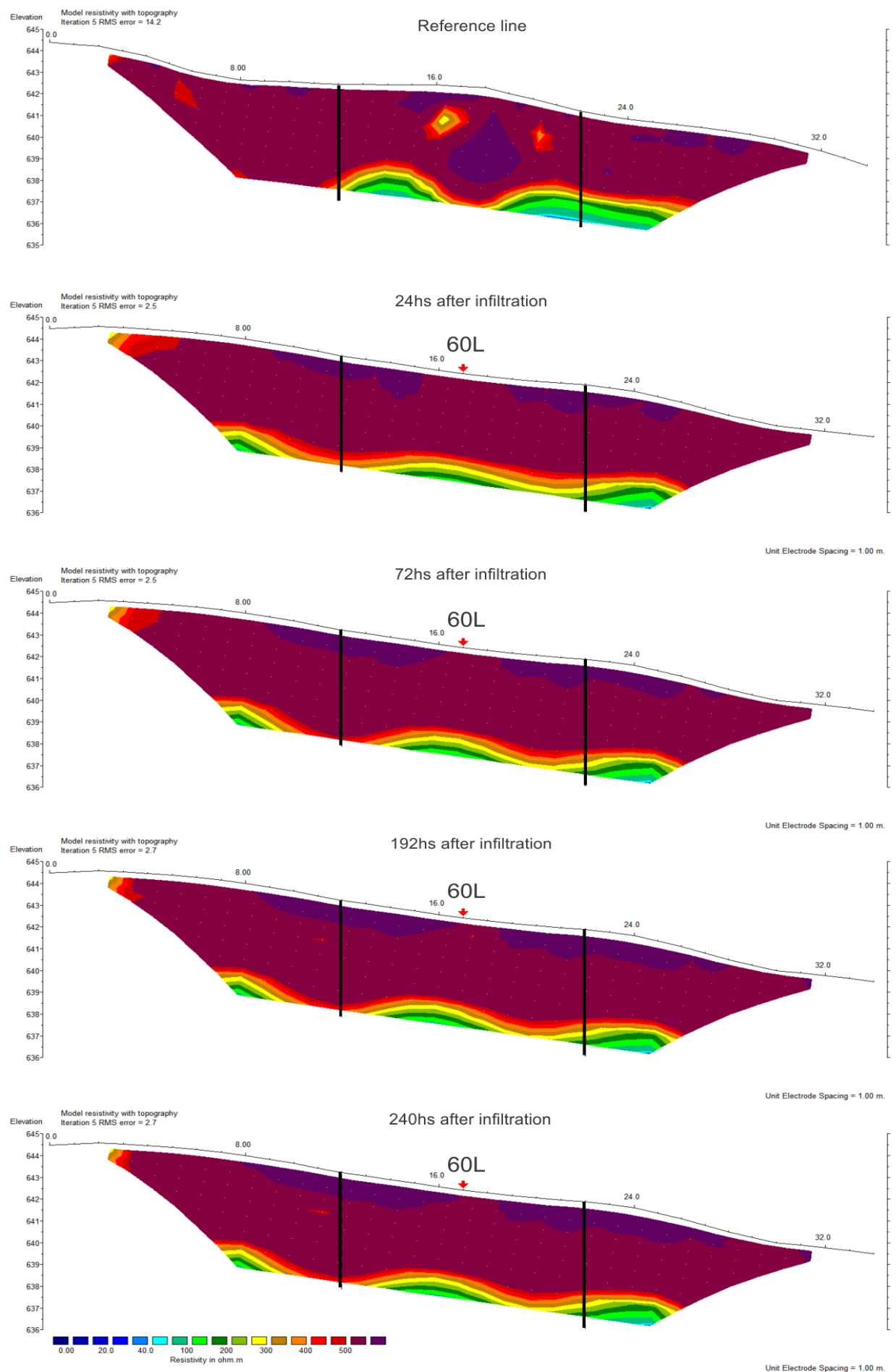

Figure 4 - Sections of electrical imaging for infiltration of 60L of stillage, with reference line measured before the experiment, limits of the central third and position of infiltration point. 

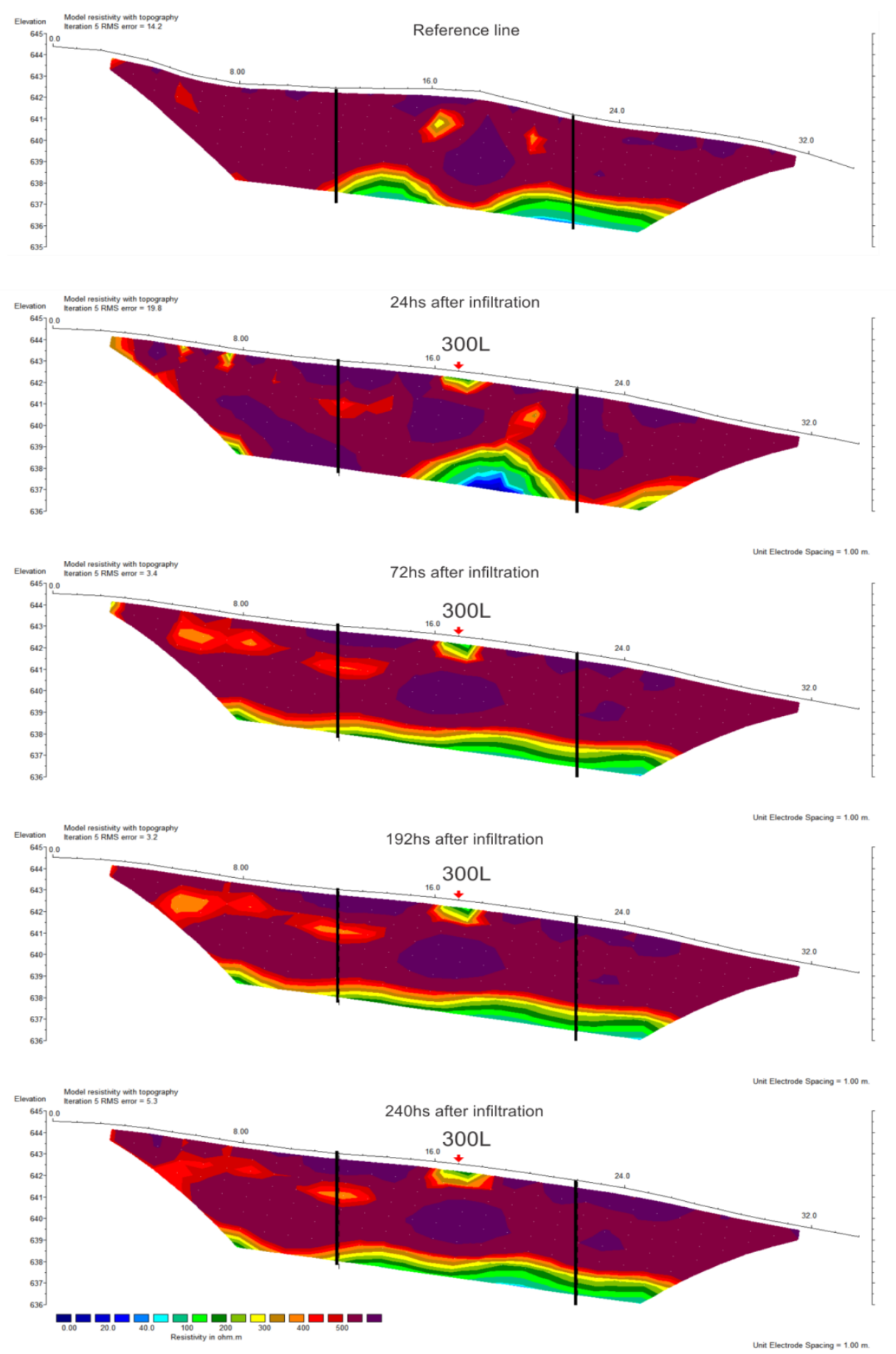

Figure 5 - Sections of electric imaging for infiltration of 300L of stillage, with reference line measured before the experiment, limits of the central third and position of infiltration point.

The geological context of the study area is characterized by thin to medium sandstones with parallel planar lamination superimposed in rough contact, by poorly developed in situ sandy soil, with a maximum thickness limited to $1 \mathrm{~m}$. In this sense, the coincidence of the limited penetration depth of the stillage flow, at $1 \mathrm{~m}$ and lateral propagation tendency evident in the dataset for $900 \mathrm{~L}$, is a clear indication of the contrasting permeability between soil and rock. The percolation is apparently limited at the soil/rock interface due to the low permeability of the rock. The experiments based on the infiltration of quantities greater than the maximum cation exchange capacity resulted in changes in the pattern of electrical resistivity of the soil, below the point of infiltration, in a very evident way. The decrease in the electrical resistivity of the soil should be attributed to the physical-chemical characteristics of stillage, water-based liquid with $7 \%$ of soluble organic matter and dissolved mineral salts. 

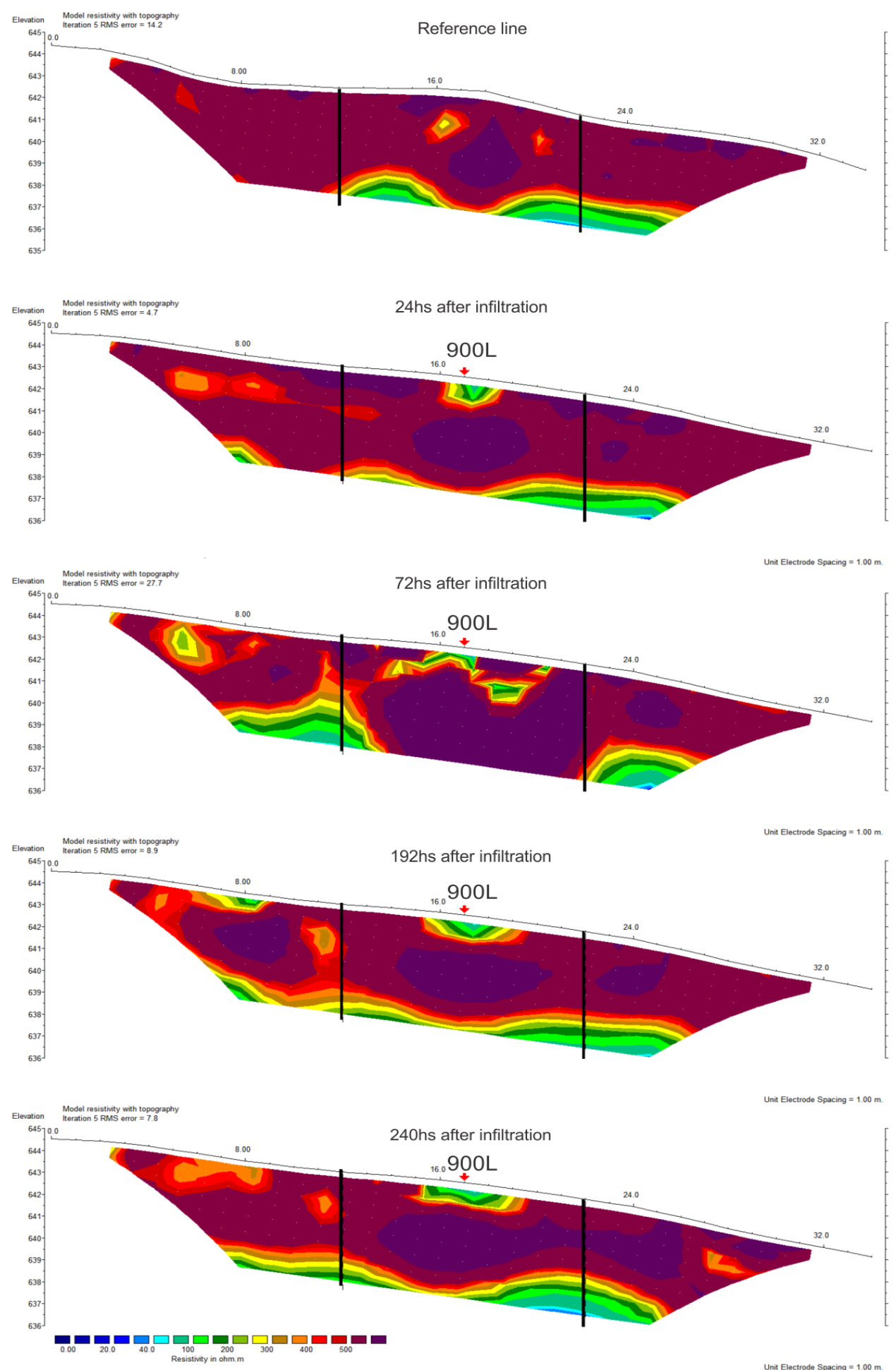

Figure 6 - Sections of electrical imaging for infiltration of 900L of stillage, with reference line measured before experiment, central third limits and infiltration point position.

The unaltered pattern, recognized in the resistivity sections, for the $60 \mathrm{~L}$ stillage infiltration experiment, reveals the occurrence of dispersion and attenuation of the degree of saturation in the soil according to the absorption capacities, that is, within the limits of cation exchange capacity of the clay minerals present in the soil. The recurrence of low resistivity areas evident below the infiltration point in the experiments for $300 \mathrm{~L}$ and $900 \mathrm{~L}$, clearly shows the percolation of an effluent volume well above the absorption capacity by cation exchange in the studied soil, with slow loss of moisture and maintenance of the dissolved solids load well beyond the experiment period.

The acid character and the high chemical and biological demand for oxygen, besides its concentration in a surface horizon of $1 \mathrm{~m}$ of soil, 
should result in a highly damaging environment to the crop, whose excess associated to the slow dispersion of the effluent, makes that a potential fertilizer becomes a toxic product to the flora and potentially harmful to the fluvial fauna. The trend of horizontal flow limited to the soil layer, under conditions of large volumes of stillage, should allow rapid access to nearby springs and drainage.

On the other hand, the data suggest a tendency of preservation of the existing aquifer at the base of the Pirambóia Formation, since the soil/rock contact represents an interface with low vertical permeability and marked lateral flow.

\section{CONCLUSIONS}

Brazil is one of the largest producers of ethanol originated from sugarcane, generating large quantities of stillage during the process of fermentation of the must in a proportion of 13 liters of stillage for each liter of ethanol produced, released directly into the rivers until 1980.

Several studies carried out in previous years have revealed the damage to river flora and fauna in stillage launching areas, and subsidized the enactment of legislation prohibiting the release of this effluent in rivers from 1980 onwards. Later studies have allowed the conversion of a residue of industrial process in an agricultural input that provided economy with inorganic fertilizers, through intensive researches focused on the capacity of absorption of the soil. These works served as a subsidy to an environmental standard for the State of São Paulo, which conditions the proportion of stillage released per square meter of land to the cation exchange capacity of the clay minerals present in each pedological domain.

The geological context of the studied area is represented by in situ low developed homogeneous sandy soil in rough contact with fine to medium sandstones, materials with hydraulic properties typical of aquifers, that is, high capacity of transmission and storage of fluids. In this environment radial percolation in vertical flow by the action of gravity would be expected from a point of superficial infiltration, also influenced by the local slope. However, the geophysical results evidenced the drastic alteration of permeability at the soil/rock interface. The poorly consolidated sandy soil allowed the rapid percolation of stillage, attenuated in contact with the rock, which has a much lower degree of permeability, and served as a flow restriction interface and base for the lateral stillage flow, conditioned to the topography of the area of the experiment.

In this sense, eventual accidents that result in the leakage of large amounts of inorganic effluents, such as stillage, should result in surface flow or at most the flow in the soil layer, with some attenuation within the cation exchange capacity, in the case of sandy soils and sandstones of the Pirambóia Formation, with eventual environmental impact in springs and drainage near the accident area and apparent preservation of the aquifer system.

These data are very relevant for the proper management of sugarcane monocultures that use stillage as fertilizer in areas of occurrence of the Pirambóia Formation, a geological unit that together with the Botucatu Formation constitutes the Guarani Aquifer System, with emphasis on areas of exposure of this unit and which are susceptible to the release of stillage. This becomes more relevant because this aquifer is a source of drinking water for the population of hundreds of Brazilian municipalities.

The results demonstrate that the release of stillage in quantities below the retention capacity of the soil does not promote changes in electrical properties, whereas the infiltration of higher volumes results in clear contrasts in electrical properties. This fact reveals the possibility of reconnaissance and monitoring of stillage contamination in the geological environment through the combined use of electrical geophysical methods and periodic chemical analysis of groundwater.

\section{ACKNOWLEDGEMENTS}

The authors are grateful to the Coordination of Improvement of Higher Education Personnel CAPES and to the National Council for Scientific and Technological Development - CNPq, for a scholarship granted, and to the Foundation for Support of Scientific Research of the State of São Paulo - FAPESP (Proc. 2011 / 21659-5) by financial support. 


\section{REFERENCES}

BRASIL. Gabinete da Presidência da República. Decreto $\mathbf{n}^{\mathbf{0}}$ 76.593, de 14/11/1975. Institui o Programa Nacional do Álcool e dá outras Providências.

BRITO, F.L.; ROLIM, M.M.; PEDROSA, E.M.R. Concentração de cátions presentes no lixiviado de solos tratados com vinhaça. Revista Engenharia Agrícola, Jaboticabal, v. 27, n. 3, p. 773-781, 2007.

CETESB-COMPANHIA AMBIENTAL DO ESTADO DE SÃO PAULO. A Produção mais Limpa $(\mathbf{P}+\mathbf{L})$ no setor sucroalcooleiro: informações gerais. CETESB, São Paulo, 2002.

CETESB-COMPANHIA AMBIENTAL DO ESTADO DE SÃO PAULO. P4.321. Vinhaça - critérios e procedimentos para aplicação no solo agrícola. 2006. Disp. em: <http://www.cetesb.sp.gov.br/Tecnologia/camaras/P4_231.pdf $>$. Acesso em: 22 set. 2010.

CONAB-COMPANHIA NACIONAL DE ABASTECIMENTO. Perfil do setor do açúcar e do álcool no Brasil volume 5 - safra 2011/2012. Brasília: CONAB, 2013. Disp. em: <http://www.conab.gov.br/OlalaCMS/uploads/arquivos/ 13_10_02_11_28_41_perfil_sucro_2012.pdf>. Acesso em: 07 mai. 2015.

CONAB - COMPANHIA NACIONAL DE ABASTECIMENTO. Acompanhamento da safra brasileira de cana-deaçúcar, v. 1 - safra 2014/15, n. 4 - quarto levantamento. 2015. Disp. em: <http://www.conab.gov.br/OlalaCMS/ uploads/arquivos/15_04_13_08_45_51_boletim_cana_portugu es_-_4o_lev_-_14-15.pdf $>$. Acessado em: 03 jul. 2015.

CRUZ, J.I. Detecção da influência da vinhaça na resistividade do solo através da análise de dados geofísicos: um estudo de caso no assentamento Sepé - Tiarajú - SP. Campinas, 2008, 165 p. Dissertação (Mestrado em Geociências) - Instituto de Geociências, Universidade Estadual de Campinas,.

DENATRAN-DEPARTAMENTO NACIONAL DE TRÂNSITO. Frota de veículos. Disponível em: <http://www. denatran.gov.br/frota2015.htm>. Acesso em: 07 mai. 2015.

EDWARDS, L. S. A modified pseudosection for resistivity and IP. Geophysics, v. 42, n. 5, p. 1020-1036, 1977.

ICIDCA-INSTITUTO CUBANO DE INVESTIGACIONES DE LOS DERIVADOS DE LA CAÑA DE AZÚCAR. Manual dos derivados da cana-de-açúcar. Brasília: ABIPTI, 1999. 474p.

GLOEDEN, E.; CUNHA, R.C.A.; FRACCAROLI, M.J.B.; CLEARY, R.W. The behaviour of stillage constituents in the unsaturated and saturated zones in the Botucatu aquifer recharge area. Water Science Technology, v. 24, n. 11, p. 147-157, 1991.

GRIFFITHS, D.H. \& BAKER, R.D. Two-dimensional resistivity imaging and modeling in areas of complex geology. Journal of Applied Geophysics, v. 29, n. 2, p. 211-226, 1993.

GONZÁLEZ, R.G. \& GARLOBO, C.M S. Vinhaça. In: ICIDCA - Instituto Cubano de Investigaciones de los Derivados de la Caña de Azúcar. Manual dos derivados da cana-de-açúcar. Brasília: ABIPTI, 1999. p. 435-438.

GOOGLE. Google Earth: 23K, 229125 m E, 7529950 m S. Santa Clara (CA, EUA): Google, 2012. Escala 1:2000. Acesso em: 07/11/2012.

HASSUDA, S. Impactos da infiltração da vinhaça de cana no Aquífero Bauru. São Paulo, 1989, 92 p. Dissertação (Mestrado)Instituto de Geociências, Universidade de São Paulo.

HASSUDA, S.; REBOUÇAS, A.C.; CUNHA, R.C.A. Aspectos qualitativos da infiltração da vinhaça de cana no aqüífero Bauru. Revista do Instituto Geológico, v. 11, n. 2, p. 5-20, 1990.
KEAREY, P.; BROOKS, M.; HILL, I. An introduction to geophysical exploration. 3. ed. Oxford: Blackwell Science, 262 p., 2002.

LOKE, M.H. \& BAKER, R.D., Rapid least-squares inversion of apparent resistivity pseudosections by quasi-Newton method. Geophysical Prospecting, v. 44, p. 131-152, 1996.

LOPES, R. C.; MARCONATO, A. P3T1p - Formação Pirambóia. In: MARCONATO, A.; TURRA, B.B.; SALVADOR, E.D.; CHIEREGATI, L.A.; D'AGOSTINO, L.Z.; PERROTA, M.M.; LOPES, R.C. Mapa Geológico do Estado de São Paulo: escala 1:750.000: breve descrição das unidades litoestratigráficas aflorantes no Estado de São Paulo. São Paulo: CPRM - Serviço Geológico do Brasil, p. 144, 2005.

LUDOVICE, M.T.F. Estudo do efeito poluente da vinhaça infiltrada em canal condutor de terra sobre lençol freático. Campinas, 1997, 143 p. Dissertação (Mestrado em Engenharia Civil)-Programa de Pós-Graduação em Engenharia Civil, Universidade Estadual de Campinas.

LYRA, M.R.C.C.; ROLIM, M.M.; SILVA, J.A.A. Topossequiência de solos fertigados com vinhaça: contribuição para a qualidade das águas do lençol freático. Revista Brasileira de Engenharia Agrícola e Ambiental, Campina Grande, v. 7, n. 3, p. 525-532, 2003.

MELLO, V.F.B. \& TEIXEIRA, A.H. Mecânica dos solos. Universidade de São Paulo: São Carlos, , 205 p., 1967.

OLIVA, A. \& CHANG, H K. Técnicas de imageamento elétrico 2D e 3D na identificação de vinhaça em subsuperfície. In: CONGRESSO INTERNACIONAL DE MEIO AMBIENTE SUBTERRÂNEO, 2, São Paulo, 2011. Anais... São Paulo: Associação Brasileira de Águas Subterrânea, 2011.

SANTOS, M.A. Fontes de energia nova e renovável. Rio de Janeiro: LTC, 2013, 197p.

SCHNEIDER, R.L.; MÜHLMANN, H.; TOMMASI, E.; MEDEIROS, R.A.; DAEMON, R.F.; NOGUEIRA, A.A. Revisão estratigráfica da Bacia do Paraná. In: CONGRESSO BRASILEIRO DE GEOLOGIA, 28, Porto Alegre, 1974. Anais... Porto Alegre: Sociedade Brasileira de Geologia, 1974, v. 1, p. 41-65.

SILVA, A.J.N.; CABEDA, M.S.V.; CARVALHO, F.G.; LIMA, J.F.W.F. Alterações físicas e químicas de um Argissolo amarelo sob diferentes sistemas de uso e manejo. Revista Brasileira de Engenharia Agrícola e Ambiental, Campina Grande, v. 10, n. 1, p. 76-83, 2006.

SILVA, J.R.S.; GODOI, F.F.F.; PROFETA, F.A.; SILVA FILHO, A.M.; OLIVEIRA, S.B.; CALIXTO, W.P.; ALVES, A.J.; MIRANDA, M.C.C. Análise da influência da aplicação de vinhaça no solo através de método de prospecção geoelétrico. In: CONGRESSO BRASILEIRO DE GEOLOGIA, 47, Salvador, 2014. Anais... São Paulo: Sociedade Brasileira de Geologia, 2014.

TELFORD, W.M.; GELDART, L.P.; SHERIFF, R.E. Applied Geophysics. 2.ed. Cambridge: Cambridge University Press, 744 p., 1990

WARD, S.H. Resistivity and induced polarization methods. In: GEOTECHNICAL AND ENVIRONMENTAL GEOPHYSICS. 1990. Tulsa, Oklahoma: Society of Exploration Geophysicists, v. 1.p., 147-189. 